\title{
Serotonergic modulation of post-synaptic inhibition and locomotor alternating pattern in the spinal cord
}

\author{
Florian Gackière and Laurent Vinay* \\ Institut de Neurosciences de la Timone, UMR 7289, CNRS, Aix Marseille Université, Marseille, France
}

\section{Edited by:}

Shawn Hochman, Emory University,

USA

Reviewed by:

Pete Wenner, Emory University, USA

Jorge Noel Quevedo, Centro de Investigación y de Estudios Avanzados (CINVESTAV), Mexico

Michael O'Donovan, National

Institutes of Health, USA

*Correspondence:

Laurent Vinay, Institut de

Neurosciences de la Timone

UMR 7289, CNRS, Aix Marseille

Université, Campus Santé Timone,

27, Boulevard Jean Moulin

13385 Marseille cx 5, France e-mail: laurent.vinay@univ-amu.fr
The central pattern generators (CPGs) for locomotion, located in the lumbar spinal cord, are functional at birth in the rat. Their maturation occurs during the last few days preceding birth, a period during which the first projections from the brainstem start to reach the lumbar enlargement of the spinal cord. Locomotor burst activity in the mature intact spinal cord alternates between flexor and extensor motoneurons through reciprocal inhibition and between left and right sides through commisural inhibitory interneurons. By contrast, all motor bursts are in phase in the fetus. The alternating pattern disappears after neonatal spinal cord transection which suppresses supraspinal influences upon the locomotor networks. This article will review the role of serotonin (5-HT), in particular $5-\mathrm{HT}_{2}$ receptors, in shaping the alternating pattern. For instance, pharmacological activation of these receptors restores the left-right alternation after injury. Experiments aimed at either reducing the endogenous level of serotonin in the spinal cord or blocking the activation of $5-\mathrm{HT}_{2}$ receptors. We then describe recent evidence that the action of $5-\mathrm{HT}_{2}$ receptors is mediated, at least in part, through a modulation of chloride homeostasis. The postsynaptic action of GABA and glycine depends on the intracellular concentration of chloride ions which is regulated by a protein in the plasma membrane, the $\mathrm{K}^{+}-\mathrm{Cl}^{-}$cotransporter (KCC2) extruding both $\mathrm{K}^{+}$and $\mathrm{Cl}^{-}$ions. Absence or reduction of $\mathrm{KCC} 2$ expression leads to a depolarizing action of GABA and glycine and a marked reduction in the strength of postsynaptic inhibition. This latter situation is observed early during development and in several pathological conditions, such as after spinal cord injury, thereby causing spasticity and chronic pain. It was recently shown that specific activation of $5-\mathrm{HT}_{2 \mathrm{~A}}$ receptors is able to up-regulate $\mathrm{KCC} 2$, restore endogenous inhibition and reduce spasticity.

Keywords: 5-HT2A receptor, 5-HT7 receptor, chloride homeostasis, KCC2 transporter, reciprocal inhibition

\section{INTRODUCTION}

It is well established that the basic rhythmic activity underlying locomotion is generated by interneuronal networks within the spinal cord called central pattern generators (CPGs; Grillner and Wallén, 1985). These are functional at birth in the rat as shown by experiments using in vitro spinal cord preparations isolated from neonates (Cazalets et al., 1992). In these preparations, the most effective pharmacological cocktails to induce fictive locomotion include serotonin (5-HT; Cazalets et al., 1992; Madriaga et al., 2004). There is considerable evidence that 5 -HT plays a key role in locomotion. Chronic recordings from 5-HT neurons in awake cats demonstrated a correlation between single unit activity and locomotor activity (Veasey et al., 1995) suggesting that the 5-HT system facilitates motor output and concurrently inhibits sensory information processing (Jacobs and Fornal, 1993). Stimulation of a discrete population of 5-HT neurons in the parapyramidal region (PPR) of the medulla elicits locomotor-like activity in the neonatal rat isolated brain stem-spinal cord preparation (Liu and Jordan, 2005). Most locomotor-activated cells, as revealed by expression of the activity-dependent marker $c$-fos, co-localize with 5- $\mathrm{HT}_{7}, 5-\mathrm{HT}_{2 \mathrm{~A}}$, and $5-\mathrm{HT}_{1 \mathrm{~A}}$ receptors (Noga et al., 2009). The intrinsic 5-HT system contributes significantly to locomotor pattern generation (Zhang and Grillner, 2000; Pearlstein et al., 2005, 2011). In addition, there is increasing evidence that recovery of locomotion after spinal cord injury (SCI) can be facilitated by systemic or intrathecal application of 5-HT or various 5-HT receptor agonists (Feraboli-Lohnherr et al., 1999; Kim et al., 2001; Antri et al., 2002, 2005; Landry et al., 2006), or transplantation of embryonic 5-HT neurons into the spinal cord caudal to the lesion (Feraboli-Lohnherr et al., 1997; Ribotta et al., 1998a,b, 2000; Kim et al., 1999; Sławińska et al., 2000, 2013; Majczyński et al., 2005).

Serotonin has a number of effects on the spinal cord, including the control of motoneuron and interneuron excitability and afferent transmission (Schmidt and Jordan, 2000; Abbinanti and Harris-Warrick, 2012; Abbinanti et al., 2012). The present review will focus on the contribution of 5-HT, with emphasis on 5- $\mathrm{HT}_{2}$ and $5-\mathrm{HT}_{7}$ receptors, in shaping the alternating pattern, and on one of the mechanisms underlying this effect, strengthening of post-synaptic inhibition, by modulation of chloride homeostasis. 


\section{ENDOGENOUS SEROTONIN IS IMPORTANT FOR THE EXPRESSION OF A LEFT-RIGHT ALTERNATING PATTERN}

Pharmacological activation of the CPGs in vitro in newborn animals evokes a fictive locomotor pattern consisting of alternation of motor bursts between both the left and right sides of the lumbar spinal cord, and flexors and extensors on one side (Cazalets et al., 1992; Kiehn and Kjaerulff, 1996). On the embryonic day (E)16 (i.e., 5 days prior to birth), the same kind of experiments reveal a motor pattern with all bursts in phase (Iizuka et al., 1998; Nakayama et al., 2002). In rats, the transition from left-right synchrony to alternation occurs around E18 and is due to the maturation of inhibitory connections between the two sides, and a shift in GABA/glycine synaptic potentials from excitation to inhibition (Wu et al., 1992; see below).

These major changes in locomotor network operation occur shortly after the arrival in the lumbar enlargement of the first axons descending from the brainstem, suggesting that descending pathways may contribute to the maturation of spinal networks (Vinay et al., 2000, 2002). Serotonergic fibers start to arrive in the lumbar gray matter by E17 (Bregman, 1987; Rajaofetra et al., 1989). Projections arising from the raphe nuclei are among the earliest axons to reach the upper lumbar segments in the rat (Lakke, 1997). They are the source of almost all the 5-HT in the lumbar spinal cord in mammals (reviewed by Schmidt and Jordan, 2000).

A number of experiments support the conclusion that descending pathways, in particular 5-HT projections, play a role in the maturation and/or the operation of the lumbar CPG. Daily in vivo injections of p-chloro-phenylalanine (PCPA), a 5-HT synthesis inhibitor, starting the day of birth markedly reduce 5HT immunoreactivity in the lumbar enlargement within 3-4 days (Pflieger et al., 2002). Depletion of endogenous 5-HT during early postnatal development induces an asymmetry of posture (Pflieger et al., 2002) and deficits in locomotion (Myoga et al., 1995), both of which indicate that the interlimb coordination is impaired. In addition, kittens or rats that have undergone a complete spinal cord transection at birth exhibit synchronous air stepping during the first postnatal week (Bradley and Smith, 1988a,b; Norreel et al., 2003). Quipazine, a 5- $\mathrm{HT}_{2}$ receptor agonist promotes alternating air stepping in intact neonatal rats (Brumley et al., 2012). The $5-\mathrm{HT}_{7}$ receptors also appear to play an important role as the antagonist, SB-269970, applied directly to the spinal cord consistently disrupts locomotion in adult mice (Liu et al., 2009).

In vitro experiments showed that 5-HT, when added with $\mathrm{N}$-methyl-d,l-aspartate (NMA) to neonatal rat isolated spinal cord preparations, strongly strengthens left/right and flexor/extensor alternation, an effect that is at least partly dependent on activation of $5-\mathrm{HT}_{2}$ receptors (Figures 1A,B; Pearlstein et al., 2005). The NMA-induced motor pattern is strongly affected in PCPA-treated animals (Pearlstein et al., 2005). Both left/right and L3-L5 alternations are weak but recover after adding 5-HT (Figure 1B). A contribution of endogenous 5-HT is further supported by the observations that ketanserin (a 5- $\mathrm{HT}_{2}$ receptor antagonist, Figure 1B) or SB-269970 (a 5- $\mathrm{HT}_{7}$ receptor antagonist, Figure 1B) disorganizes the locomotor pattern (makes the cross-correlation coefficient less negative) induced by either NMA (Pearlstein et al., 2005; Liu et al., 2009; Jordan and Slawinska, 2011) or electrical stimulation of the brainstem (Liu and Jordan, 2005). Finally, in spinal cords isolated from $5-\mathrm{HT}_{7}$ receptor knock-out mice, 5-HT produces either uncoordinated rhythmic activity or results in synchronous discharges of the ventral roots (Liu et al., 2009).

Together, these observations suggest that $5-\mathrm{HT}_{2}$ and $5-\mathrm{HT}_{7}$ receptors appear to mediate the effect of serotonin to enhance and stabilize both left-right and flexor-extensor alternation. Other 5-HT receptors, such as 5- $\mathrm{HT}_{1 \mathrm{~A}}$, may have an opposite effect to reduce reciprocal inhibition as shown in Xenopus laevis (Wedderburn and Sillar, 1994; McDearmid et al., 1997).

\section{THE STRENGTH OF POSTSYNAPTIC INHIBITION IS REDUCED AFTER SCI DUE TO A DYSREGULATION OF CHLORIDE HOMEOSTASIS}

Ipsilateral co-contraction of flexors and extensors is commonly observed in SCI patients (Harkema, 2008). The strength of several well-characterized inhibitory mechanisms such as presynaptic (Katz, 1999), recurrent (Mazzocchio and Rossi, 1997) and reciprocal (Boorman et al., 1996) inhibition is reduced after SCI. A reciprocal facilitation, instead of reciprocal inhibition, may even appear (Crone et al., 2003). Similarly, crossed inhibition of contralateral motoneurons by group II muscle afferents in intact cats is inverted to crossed excitation in spinal cats (Aggelopoulos et al., 1996). The mechanisms responsible for the decrease in strength of postsynaptic inhibition were recently identified. Briefly, in healthy mature cells, activation of $\mathrm{GABA}_{\mathrm{A}}$ and glycine receptors leads to chloride entry which causes membrane hyperpolarization. This occurs because the intracellular concentration of chloride ions $\left(\left[\mathrm{Cl}^{-}\right]_{\mathrm{i}}\right)$ is maintained at low levels by the potassiumchloride co-transporters KCC2 that extrude chloride from the cell (Payne et al., 2003; Vinay and Jean-Xavier, 2008; Blaesse et al., 2009; Chamma et al., 2012). There is now abundant evidence that an increase in $\left[\mathrm{Cl}^{-}\right]_{i}$, most often recorded/visualized as a depolarizing shift of the chloride equilibrium potential, reduces the strength of postsynaptic inhibition or may even switch it towards excitation or promote facilitation of concomitant excitatory inputs (van den Pol et al., 1996; Gao et al., 1998b; Gulledge and Stuart, 2003; Prescott et al., 2006; Jean-Xavier et al., 2007; Doyon et al., 2011).

The expression of KCC2 in the plasma membrane of lumbar motoneurons below the lesion is reduced after spinal cord injury, thereby causing a depolarizating shift in the chloride equilibrium potential (Boulenguez et al., 2010). Similar results were described in the superficial layers of the dorsal horn either after SCI (Cramer et al., 2008; Lu et al., 2008) or following peripheral nerve injury (Coull et al., 2003, 2005). These observations were shown to contribute to spasticity and chronic pain, respectively. To conclude, dysregulation of chloride homeostasis can account for the reduction in strength of postsynaptic inhibition or even a switch to facilitation after SCI. 


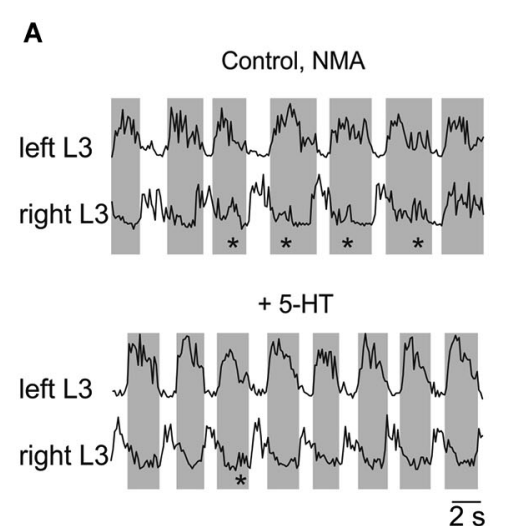

C

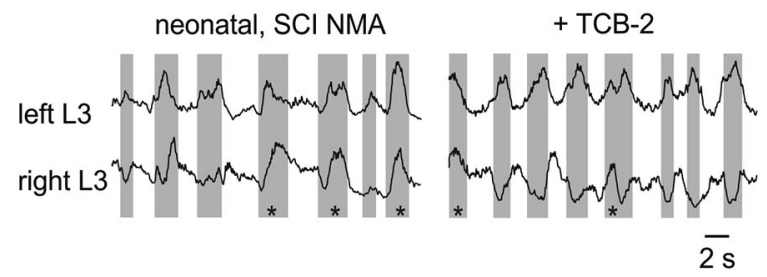

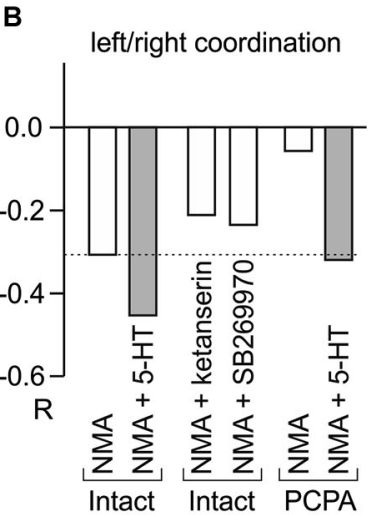

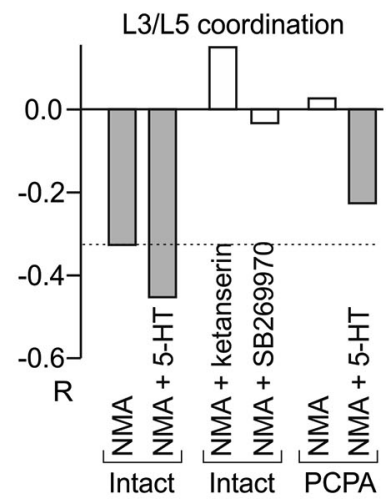

D
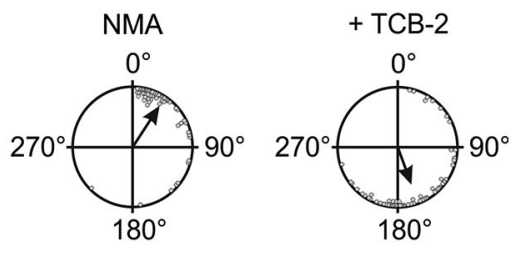

FIGURE 1 | 5-HT enhances the NMA-induced fictive locomotor pattern in the isolated neonatal rat spinal cord. (A) Activity recorded from the 3rd left and right lumbar ventral roots after rectification and integration. Bath application of NMA (18 $\mu \mathrm{M})$ induced fictive locomotion characterized by left-right alternation. Addition of 5-HT (5 $\mu \mathrm{M})$ stabilized these alternations. Note the lower occurrence of left-right concomitant bursting (asterisks). (B) Mean correlation coefficients (R) for left-right and L3/L5 relationships in various experimental conditions, after adding $5-\mathrm{HT}$, blocking $5-\mathrm{HT}_{2 \mathrm{~A}}$ receptors with ketanserin or 5- $\mathrm{HT}_{7}$ receptors with SB269970, or blocking 5-HT synthesis by PCPA. (A) and (B) are adapted from Pearlstein et al. (2005).
(C,D) Activation of $5-\mathrm{HT}_{2 \mathrm{~A}}$ receptors in vitro restores the left-right alternating locomotor pattern 5 days after neonatal spinal cord transection. (C) Integrated recordings from the left and right L3 ventral roots at P5 in the presence of NMA $(16 \mu \mathrm{M})$ alone (note the high occurrence of synchronous bursts, asterisks) or together with $5-\mathrm{HT}_{2 \mathrm{~A}}$ receptor agonist

(4-bromo-3,6-dimethoxybenzocyclobuten-1-yl) methylamine hydrobromide (TCB-2): $(0.1 \mu \mathrm{M})$. (D) Distribution of phase relationships between left and right ventral root bursts in NMA alone (Left) and NMA plus TCB-2 (Right) in all of the spinal animals (P5-P6; $n=6$ ). (C) and (D) are adapted from Bos et al. (2013).

\section{SEROTONIN ENABLES RESTORATION OF COORDINATED LOCOMOTION AFTER SPINAL CORD INJURY}

Following a neonatal spinal cord transection that disorganizes the left-right alternating pattern, left-right hindlimb alternation is restored after injecting $( \pm)$-2,5-dimethoxy-4-iodoamphetamine hydrochloride (DOI), a 5- $\mathrm{HT}_{2}$ receptor agonist (Norreel et al., 2003). In addition, however, sensory inputs from the moving limbs in vivo can also promote left-right alternations under certain circumstances. In kittens with spinal cord transection at birth, alternation is more pronounced during treadmill stepping ( $\sim 40 \%$ of alternating steps) than during air stepping $(\sim 3 \%)$, suggesting that rhythmic ground contact may promote an alternating gait (Bradley and Smith, 1988b). However, in recent experiments in intact neonatal rats, in which a substrate (elastic, stiff, or none) was placed beneath their limbs so that the feet could make plantar surface contact with the substrate, pups treated with quipazine showed significantly more alternating fore- and hindlimb steps than pups treated with saline (Brumley et al., 2012). In rats with a neonatal spinal cord transection, the fictive locomotor pattern induced by excitatory amino acids does not exhibit any left/right alternation. However, strong alternation is restored when $5-\mathrm{HT}$ is added to the bath (Norreel et al., 2003).
Serotonergic $5-\mathrm{HT}_{2}$ and $5-\mathrm{HT}_{7}$ receptor agonists have repeatedly been shown to promote locomotor recovery after SCI in adult rodents (Barbeau and Rossignol, 1990; Antri et al., 2002; Kao et al., 2006; Landry et al., 2006; Ung et al., 2008; Courtine et al., 2009; Murray et al., 2010; Jordan and Slawinska, 2011; Musienko et al., 2011; van den Brand et al., 2012). Combined activation of both receptor subtypes is more effective than activation of either receptor alone (Antri et al., 2005; Landry et al., 2006; Courtine et al., 2009; Sławińska et al., 2012). In rats with a complete thoracic spinal cord transection, grafts of embryonic serotonergic neurons improve locomotor recovery (Feraboli-Lohnherr et al., 1997; Ribotta et al., 2000; Majczyński et al., 2005; Sławińska et al., 2013). Importantly, both inter- and intralimb coordinations are improved by grafting embryonic 5-HT neurons after SCI in adult rats and the effectiveness of the transplants arises from intrinsic activation of $5-\mathrm{HT}_{2}$ and $5-\mathrm{HT}_{7}$ receptors (Sławińska et al., 2000, 2013).

\section{MODULATION OF INHIBITORY SYNAPTIC TRANSMISSION BY 5-HT 2 AND 5- HT $_{7}$ RECEPTORS}

There are, in principle, various ways through which 5-HT may strengthen inhibitory synaptic transmission. The most obvious explanation for the improvement of inter- and intralimb 
alternating motor activity following activation of $5-\mathrm{HT}_{2}$ and $5-\mathrm{HT}_{7}$ receptors is that this activation excites inhibitory interneurons responsible for coordinating flexor/extensor and left/right activity (Aggelopoulos et al., 1996; Pearlstein et al., 2005; Sławińska et al., 2013). Exogenously applied 5-HT (Lewis et al., 1993; Shen and Andrade, 1998; Abi-Saab et al., 1999; Xie et al., 2012) and endogenous 5-HT (Iwasaki et al., 2013) have been shown to activate GABAergic and/or glycinergic interneurons via $5-\mathrm{HT}_{2}$ receptors in the CNS including the spinal cord. Activation of $5-\mathrm{HT}_{2 \mathrm{~A} / 2 \mathrm{C}}$ receptors enhances glycine and/or GABA responses in spinal neurons in the rat (Xu et al., 1996, 1998; Li et al., 2000) and spontaneous inhibitory postsynaptic currents in the substantia gelatinosa (Xie et al., 2012). These effects involve, at least in part, a presynaptic facilitation of GABA/glycine release (Wang and Zucker, 1998; Xie et al., 2012). It has been shown that $5-\mathrm{HT}_{7}$ receptor activation in the hippocampal CA1 area results in an enhancement of GABAergic transmission via two mechanisms (Tokarski et al., 2011). The first one involves an enhancement of excitatory glutamatergic input to GABAergic interneurons and is likely to be mediated by presynaptic $5-\mathrm{HT}_{7}$ receptors. The second effect, most likely related to the activation of $5-\mathrm{HT}_{7}$ receptors located on interneurons, results in an enhancement of GABA release.

Developmental studies provide interesting information about 5-HT modulation of inhibitory synaptic transmission. Maturation of inhibition in the lumbar spinal cord occurs during perinatal development in rodents. The key events are as follows: (1) the density of glycine currents (Gao and Ziskind-Conhaim, 1995) and receptors (Sadlaoud et al., 2010) increases whereas that of $\mathrm{GABA}_{\mathrm{A}}$ currents and receptors drop concomitantly. (2) Inhibitory postsynaptic potentials switch from depolarizing to hyperpolarizing (Takahashi, 1984; Wu et al., 1992; Gao et al., 1998a; JeanXavier et al., 2006; Delpy et al., 2008; Stil et al., 2011), mostly due to the up-regulation of KCC2 expression (Jean-Xavier et al., 2006; Stil et al., 2009). A neonatal spinal cord transection at birth, which removes all descending modulatory influences from the brainstem, prevents both the depolarization-to-hyperpolarization switch (Jean-Xavier et al., 2006; Bos et al., 2013) and the developmental down-regulation of $\mathrm{GABA}_{\mathrm{A}}$ currents and receptors (Sadlaoud et al., 2010). Interestingly, up-regulation of glycine receptors is not affected by spinal transection. Chronic treatment with the $5-\mathrm{HT}_{2}$ receptor agonist, DOI, throughout the first postnatal week restores the hyperpolarizing shift of the chloride equilibrium potential (Bos et al., 2013) and the down-regulation of $\mathrm{GABA}_{\mathrm{A}}$ receptors, without any significant effect on glycine receptors (Sadlaoud et al., 2010). These data suggested that 5-HT plays a role in the maturation of GABAergic synaptic transmission but that the up-regulation of glycinergic receptors does not depend on descending modulation from the brainstem.

Because the strength of inhibition depends on $\left[\mathrm{Cl}^{-}\right]_{i}$, 5-HT, in principle, may strengthen inhibitory synaptic transmission by increasing KCC2 function. This hypothesis is supported by recent results showing that activation of 5$\mathrm{HT}_{2 \mathrm{~A}}$ receptors shifts the chloride equilibrium potential in the hyperpolarizing direction (Bos et al., 2013). This effect is mediated by an up-regulation of KCC2 function and involves a protein kinase $\mathrm{C}$ (PKC)-dependent mechanism. After SCI, acute addition of a specific $5-\mathrm{HT}_{2 \mathrm{~A}}$ receptor agonist, TCB-2, restores endogenous inhibition and thereby reduces spasticity and restores left-right alternation during fictive locomotion (Figures 1C,D; Bos et al., 2013). Interestingly, 5- $\mathrm{HT}_{2 \mathrm{~A}}$ and $5-\mathrm{HT}_{2 \mathrm{~B} / 2 \mathrm{C}}$ receptors were shown in the latter study to have opposite effects on KCC2 function. Consistent with these observations, $5-\mathrm{HT}_{2 \mathrm{~A}}$ and $5-\mathrm{HT}_{2 \mathrm{C}}$ receptors exert opposing effects on both locomotor activity in mice and spinal reflexes in rats (Machacek et al., 2001; Halberstadt et al., 2009). As 5- $\mathrm{HT}_{2 \mathrm{~B} / 2 \mathrm{C}}$ receptors become constitutively active (spontaneously active without 5-HT) after SCI (Murray et al., 2010, 2011), this constitutive activity may be partly responsible for the depolarizing shift of the chloride equilibrium potential after SCI (Boulenguez et al., 2010).

\section{CONCLUSIONS AND FUTURE DIRECTIONS}

This review has shown that 5-HT plays a critical role in shaping the locomotor pattern by promoting left-right and flexor-extensor alternation, thereby raising the question of whether serotonin descending systems should be formally included as components of the CPGs for locomotion (Jordan and Slawinska, 2011). According to the initial definition of CPGs (Grillner and Wallén, 1985), "the term CPGs refers to function, not a circumscribed anatomical entity. The individual neurons that constitute the CPG may in principle be located in widely separate parts of the central nervous system".

As combined exogenous application of both $5-\mathrm{HT}_{7}$ and 5$\mathrm{HT}_{2}$ receptor agonists is more effective than activation of either of these receptors alone (Antri et al., 2005; Landry et al., 2006; Musienko et al., 2011; Sławińska et al., 2012), it will be important to identify whether the mechanisms by which $5-\mathrm{HT}_{7}$ receptors affect alternating motor activities also involve chloride homeostasis as is the case for $5-\mathrm{HT}_{2 \mathrm{~A}}$ receptors. Although the present review focused on serotonin, SCI removes not only serotonergic inputs but also dopaminergic and noradrenergic inputs to neurons below the lesion. The contribution of these pathways to the alternating locomotor pattern and regulation of chloride homeostasis should be investigated further.

\section{ACKNOWLEDGMENTS}

Our study on the plasticity of inhibitory synaptic transmission in the spinal cord is supported by grants (to Laurent Vinay ) from the French Agence Nationale pour la Recherche (ANR 2010BLAN-1407-01), the Institut pour la Recherche sur la Moelle épinière et l'Encéphale, the Fondation pour la Recherche Médicale (DEQ20130326540) and the International Spinal Reseach Trust (STR110). We thank Ron Harris-Warrick for critical reading of the manuscript.

\section{REFERENCES}

Abbinanti, M. D., and Harris-Warrick, R. M. (2012). Serotonin modulates multiple calcium current subtypes in commissural interneurons of the neonatal mouse. J. Neurophysiol. 107, 2212-2219. doi: 10.1152/jn.00768.2011

Abbinanti, M. D., Zhong, G., and Harris-Warrick, R. M. (2012). Postnatal emergence of serotonin-induced plateau potentials in commissural interneurons of the mouse spinal cord. J. Neurophysiol. 108, 2191-2202. doi: 10.1152/jn.00336. 2012

Abi-Saab, W. M., Bubser, M., Roth, R. H., and Deutch, A. Y. (1999). 5-HT2 receptor regulation of extracellular GABA levels in the prefrontal cortex. Neuropsychopharmacology 20, 92-96. doi: 10.1016/s0893-133x(98)00046-3 
Aggelopoulos, N. C., Burton, M. J., Clarke, R. W., and Edgley, S. A. (1996). Characterization of a descending system that enables crossed group II inhibitory reflex pathways in the cat spinal cord. J. Neurosci. 16, 723-729.

Antri, M., Barthe, J. Y., Mouffle, C., and Orsal, D. (2005). Long-lasting recovery of locomotor function in chronic spinal rat following chronic combined pharmacological stimulation of serotonergic receptors with 8-OHDPAT and quipazine. Neurosci. Lett. 384, 162-167. doi: 10.1016/j.neulet.2005.04.062

Antri, M., Orsal, D., and Barthe, J. Y. (2002). Locomotor recovery in the chronic spinal rat: effects of long-term treatment with a 5-HT2 agonist. Eur. J. Neurosci. 16, 467-476. doi: 10.1046/j.1460-9568.2002.02088.x

Barbeau, H., and Rossignol, S. (1990). The effects of serotonergic drugs on the locomotor pattern and on cutaneous reflexes of the adult chronic spinal cat. Brain Res. 514, 55-67. doi: 10.1016/0006-8993(90)90435-e

Blaesse, P., Airaksinen, M. S., Rivera, C., and Kaila, K. (2009). Cation-chloride cotransporters and neuronal function. Neuron 61, 820-838. doi: 10.1016/j. neuron.2009.03.003

Boorman, G. I., Lee, R. G., Becker, W. J., and Windhorst, U. R. (1996). Impaired "natural reciprocal inhibition" in patients with spasticity due to incomplete spinal cord injury. Electroencephalogr. Clin. Neurophysiol. 101, 84-92. doi: 10. 1016/0924-980x(95)00262-j

Bos, R., Sadlaoud, K., Boulenguez, P., Buttigieg, D., Liabeuf, S., Brocard, C., et al. (2013). Activation of 5-HT2A receptors upregulates the function of the neuronal K-Cl cotransporter KCC2. Proc. Natl. Acad. Sci. U S A 110, 348-353. doi: 10. 1073/pnas.1213680110

Boulenguez, P., Liabeuf, S., Bos, R., Bras, H., Jean-Xavier, C., Brocard, C., et al. (2010). Down-regulation of the potassium-chloride cotransporter KCC2 contributes to spasticity after spinal cord injury. Nat. Med. 16, 302-307. doi: 10 . 1038/nm.2107

Bradley, N. S., and Smith, J. L. (1988a). Neuromuscular patterns of stereotypic hindlimb behaviors in the first two postnatal months. I. Stepping in normal kittens. Brain Res. 466, 37-52. doi: 10.1016/0165-3806(88)90084-3

Bradley, N. S., and Smith, J. L. (1988b). Neuromuscular patterns of stereotypic hindlimb behaviors in the first two postnatal months. II. Stepping in spinal kittens. Brain Res. 466, 53-67. doi: 10.1016/0165-3806(88)90085-5

Bregman, B. S. (1987). Development of serotonin immunoreactivity in the rat spinal cord and its plasticity after neonatal spinal cord lesions. Brain Res. 431, 245-263.

Brumley, M. R., Roberto, M. E., and Strain, M. M. (2012). Sensory feedback modulates quipazine-induced stepping behavior in the newborn rat. Behav. Brain Res. 229, 257-264. doi: 10.1016/j.bbr.2012.01.006

Cazalets, J. R., Sqalli-Houssaini, Y., and Clarac, F. (1992). Activation of the central pattern generators for locomotion by serotonin and excitatory amino acids in neonatal rat. J. Physiol. 455, 187-204.

Chamma, I., Chevy, Q., Poncer, J. C., and Levi, S. (2012). Role of the neuronal K$\mathrm{Cl}$ co-transporter KCC2 in inhibitory and excitatory neurotransmission. Front. Cell. Neurosci. 6:5. doi: 10.3389/fncel.2012.00005

Coull, J. A., Beggs, S., Boudreau, D., Boivin, D., Tsuda, M., Inoue, K., et al. (2005). BDNF from microglia causes the shift in neuronal anion gradient underlying neuropathic pain. Nature 438, 1017-1021. doi: 10.1038/nature04223

Coull, J. A., Boudreau, D., Bachand, K., Prescott, S. A., Nault, F., Sik, A., et al. (2003). Trans-synaptic shift in anion gradient in spinal lamina I neurons as a mechanism of neuropathic pain. Nature 424, 938-942. doi: 10.1038/nature01868

Courtine, G., Gerasimenko, Y., van den Brand, R., Yew, A., Musienko, P., Zhong, H., et al. (2009). Transformation of nonfunctional spinal circuits into functional states after the loss of brain input. Nat. Neurosci. 12, 1333-1342. doi: 10.1038/nn. 2401

Cramer, S. W., Baggott, C., Cain, J., Tilghman, J., Allcock, B., Miranpuri, G., et al. (2008). The role of cation-dependent chloride transporters in neuropathic pain following spinal cord injury. Mol. Pain 4:36. doi: 10.1186/17448069-4-36

Crone, C., Johnsen, L. L., Biering-Sorensen, F., and Nielsen, J. B. (2003). Appearance of reciprocal facilitation of ankle extensors from ankle flexors in patients with stroke or spinal cord injury. Brain 126, 495-507. doi: 10.1093/brain/awg036

Delpy, A., Allain, A. E., Meyrand, P., and Branchereau, P. (2008). NKCC1 cotransporter inactivation underlies embryonic development of chloride-mediated inhibition in mouse spinal motoneuron. J. Physiol. 586, 1059-1075. doi: 10. 1113/jphysiol.2007.146993

Doyon, N., Prescott, S. A., Castonguay, A., Godin, A. G., Kroger, H., and De Koninck, Y. (2011). Efficacy of synaptic inhibition depends on, multiple., dynamically interacting mechanisms implicated in chloride homeostasis. PLoS Comput. Biol. 7:e1002149. doi: 10.1371/journal.pcbi.1002149

Feraboli-Lohnherr, D., Barthe, J. Y., and Orsal, D. (1999). Serotonin-induced activation of the network for locomotion in adult spinal rats. J. Neurosci. Res. 55 , 87-98. doi: 10.1002/(sici)1097-4547(19990101)55:1<87::aid-jnr10>3.3.co;2-r

Feraboli-Lohnherr, D., Orsal, D., Yakovleff, A., Giménez y Ribotta, M., and Privat, A. (1997). Recovery of locomotor activity in the adult chronic spinal rat after sublesional transplantation of embryonic nervous cells: specific role of serotonergic neurons. Exp. Brain Res. 113, 443-454. doi: 10.1007/pl000 05597

Gao, X. B., Chen, G., and van den Pol, A. N. (1998b). GABA-dependent firing of glutamate-evoked action potentials at AMPA/kainate receptors in developing hypothalamic neurons. J. Neurophysiol. 79, 716-726.

Gao, B. X., Cheng, G., and Ziskind-Conhaim, L. (1998a). Development of spontaneous synaptic transmission in the rat spinal cord. J. Neurophysiol. 79, 22772287.

Gao, B.-X., and Ziskind-Conhaim, L. (1995). Development of glycine- and GABAgated currents in rat spinal motoneurons. J. Neurophysiol. 74, 113-121.

Grillner, S., and Wallén, P. (1985). Central pattern generators for locomotion, with special reference to vertebrates. Annu. Rev. Neurosci. 8, 233-261. doi: 10. 1146/annurev.neuro.8.1.233

Gulledge, A. T., and Stuart, G. J. (2003). Excitatory actions of GABA in the cortex. Neuron 37, 299-309. doi: 10.1016/s0896-6273(02)01146-7

Halberstadt, A. L., van der Heijden, I., Ruderman, M. A., Risbrough, V. B., Gingrich, J. A., Geyer, M. A., et al. (2009). 5-HT(2A) and 5-HT(2C) receptors exert opposing effects on locomotor activity in mice. Neuropsychopharmacology 34, 1958-1967. doi: 10.1038/npp.2009.29

Harkema, S. J. (2008). Plasticity of interneuronal networks of the functionally isolated human spinal cord. Brain Res. Rev. 57, 255-264. doi: 10.1016/j.brainresrev. 2007.07.012

Iizuka, M., Nishimaru, H., and Kudo, N. (1998). Development of the spatial pattern of 5-HT-induced locomotor rhythm in the lumbar spinal cord of rat fetuses in vitro. Neurosci. Res. 31, 107-111. doi: 10.1016/s0168-0102(98)00029-7

Iwasaki, T., Otsuguro, K., Kobayashi, T., Ohta, T., and Ito, S. (2013). Endogenously released 5-HT inhibits $\mathrm{A}$ and $\mathrm{C}$ fiber-evoked synaptic transmission in the rat spinal cord by the facilitation of GABA/glycine and 5-HT release via 5-HT(2A) and 5-HT(3) receptors. Eur. J. Pharmacol. 702, 149-157. doi: 10.1016/j.ejphar. 2013.01.058

Jacobs, B. L., and Fornal, C. A. (1993). 5-HT and motor control: a hypothesis. Trends Neurosci. 16, 346-352. doi: 10.1016/0166-2236(93)90090-9

Jean-Xavier, C., Mentis, G. Z., O’Donovan, M., Cattaert, D., and Vinay, L. (2007). Dual personality of GABA/glycine-mediated depolarizations in the immature spinal cord. Proc. Natl. Acad. Sci. U S A 104, 11477-11482. doi: 10.1073/pnas. 0704832104

Jean-Xavier, C., Pflieger, J.-F., Liabeuf, S., and Vinay, L. (2006). Inhibitory postsynaptic potentials in lumbar motoneurons remain depolarizing after neonatal spinal cord transection in the rat. J. Neurophysiol. 96, 2274-2281. doi: 10 . 1152/jn.00328.2006

Jordan, L. M., and Slawinska, U. (2011). Chapter 12-modulation of rhythmic movement: control of coordination. Prog. Brain Res. 188, 181-195. doi: 10. 1016/B978-0-444-53825-3.00017-6

Kao, T., Shumsky, J. S., Jacob-Vadakot, S., Himes, B. T., Murray, M., and Moxon, K. A. (2006). Role of the 5-HT2C receptor in improving weight-supported stepping in adult rats spinalized as neonates. Brain Res. 1112, 159-168. doi: 10. 1016/j.brainres.2006.07.020

Katz, R. (1999). Presynaptic inhibition in humans: a comparison between normal and spastic patients. J. Physiol. Paris 93, 379-385. doi: 10.1016/s09284257(00)80065-0

Kiehn, O., and Kjaerulff, O. (1996). Spatiotemporal characteristics of 5-HT and dopamine-induced rhythmic hindlimb activity in the in vitro neonatal rat. $J$. Neurophysiol. 75, 1472-1482.

Kim, D., Adipudi, V., Shibayama, M., Giszter, S., Tessler, A., Murray, M., et al. (1999). Direct agonists for serotonin receptors enhance locomotor function in rats that received neural transplants after neonatal spinal transection. J. Neurosci. $19,6213-6224$.

Kim, D., Murray, M., and Simansky, K. J. (2001). The serotonergic 5-HT(2C) agonist $\mathrm{m}$-chlorophenylpiperazine increases weight-supported locomotion without development of tolerance in rats with spinal transections. Exp. Neurol. 169, 496500. doi: 10.1006/exnr.2001.7660 
Lakke, E. A. J. F. (1997). The projections to the spinal cord of the rat during development: a time-table of descent. Adv. Anat. Embryol. Cell Biol. 135, 1-143. doi: 10.1007/978-3-642-60601-4

Landry, E. S., Lapointe, N. P., Rouillard, C., Levesque, D., Hedlund, P. B., and Guertin, P. A. (2006). Contribution of spinal 5-HT1A and 5-HT7 receptors to locomotor-like movement induced by 8-OH-DPAT in spinal cord-transected mice. Eur. J. Neurosci. 24, 535-546. doi: 10.1111/j.1460-9568.2006.04917.x

Lewis, D. I., Sermasi, E., and Coote, J. H. (1993). Excitatory and indirect inhibitory actions of 5-hydroxytryptamine on sympathetic preganglionic neurones in the neonate rat spinal cord in vitro. Brain Res. 610, 267-275. doi: 10.1016/00068993(93)91410-t

Li, H., Lang, B., Kang, J. F., and Li, Y. Q. (2000). Serotonin potentiates the response of neurons of the superficial laminae of the rat spinal dorsal horn to gamma-aminobutyric acid. Brain Res. Bull. 52, 559-565. doi: 10.1016/s0361$9230(00) 00297-5$

Liu, J., Akay, T., Hedlund, P. B., Pearson, K. G., and Jordan, L. M. (2009). Spinal 5HT7 receptors are critical for alternating activity during locomotion: in vitro neonatal and in vivo adult studies using 5-HT7 receptor knockout mice. $J$. Neurophysiol. 102, 337-348. doi: 10.1152/jn.91239.2008

Liu, J., and Jordan, L. M. (2005). Stimulation of the parapyramidal region of the neonatal rat brain stem produces locomotor-like activity involving spinal 5-HT7 and 5-HT2A receptors. J. Neurophysiol. 94, 1392-1404. doi: 10.1152/jn.00136. 2005

Lu, Y., Zheng, J., Xiong, L., Zimmermann, M., and Yang, J. (2008). Spinal cord injury-induced attenuation of GABAergic inhibition in spinal dorsal horn circuits is associated with down-regulation of the chloride transporter KCC2 in rat. J. Physiol. 586, 5701-5715. doi: 10.1113/jphysiol.2008. 152348

Machacek, D. W., Garraway, S. M., Shay, B. L., and Hochman, S. (2001). Serotonin 5-HT(2) receptor activation induces a long-lasting amplification of spinal reflex actions in the rat. J. Physiol. 537, 201-207. doi: 10.1111/j.1469-7793.2001. 0201k.x

Madriaga, M. A., McPhee, L. C., Chersa, T., Christie, K. J., and Whelan, P. J. (2004), Modulation of locomotor activity by multiple 5 - $\mathrm{HT}$ and dopaminergic receptor subtypes in the neonatal mouse spinal cord. J. Neurophysiol. 92, 1566-1576. doi: $10.1152 /$ jn. 01181.2003

Majczyński, H., Maleszak, K., Cabaj, A., and Slawinska, U. (2005). Serotoninrelated enhancement of recovery of hind limb motor functions in spinal rats after grafting of embryonic raphe nuclei. J. Neurotrauma 22, 590-604. doi: 10. 1089/neu.2005.22.590

Mazzocchio, R., and Rossi, A. (1997). Involvement of spinal recurrent inhibition in spasticity. Further insight into the regulation of Renshaw cell activity. Brain 120(Pt. 6), 991-1003. doi: 10.1093/brain/120.6.991

McDearmid, J. R., Scrymgeour-Wedderburn, J. F., and Sillar, K. T. (1997). Aminergic modulation of glycine release in a spinal network controlling swimming in Xenopus laevis. J. Physiol. 503(Pt. 1), 111-117. doi: 10.1111/j.1469-7793.1997. 111bi.x

Murray, K. C., Nakae, A., Stephens, M. J., Rank, M., D’Amico, J., Harvey, P. J., et al. (2010). Recovery of motoneuron and locomotor function after spinal cord injury depends on constitutive activity in 5-HT2C receptors. Nat. Med. 16, 694700. doi: $10.1038 / \mathrm{nm} .2160$

Murray, K. C., Stephens, M. J., Ballou, E. W., Heckman, C. J., and Bennett, D. J. (2011). Motoneuron excitability and muscle spasms are regulated by 5-HT2B and 5-HT2C receptor activity. J. Neurophysiol. 105, 731-748. doi: 10.1152/jn. 00774.2010

Musienko, P., van den Brand, R., Marzendorfer, O., Roy, R. R., Gerasimenko, Y., Edgerton, V. R., et al. (2011). Controlling specific locomotor behaviors through multidimensional monoaminergic modulation of spinal circuitries. J. Neurosci. 31, 9264-9278. doi: 10.1523/JNEUROSCI.5796-10.2011

Myoga, H., Nonaka, S., Matsuyama, K., and Mori, S. (1995). Postnatal development of locomotor movements in normal and para-chlorophenylalanine-treated newborn rats. Neurosci. Res. 21, 211-221. doi: 10.1016/0168-0102(94)00857-c

Nakayama, K., Nishimaru, H., and Kudo, N. (2002). Basis of changes in left-right coordination of rhythmic motor activity during development in the rat spinal cord. J. Neurosci. 22, 10388-10398.

Noga, B. R., Johnson, D. M., Riesgo, M. I., and Pinzon, A. (2009). Locomotoractivated neurons of the cat. I. Serotonergic innervation and co-localization of 5-HT7, 5-HT2A and 5-HT1A receptors in the thoraco-lumbar spinal cord. J. Neurophysiol. 102, 1560-1576. doi: 10.1152/jn.91179.2008
Norreel, J.-C., Pflieger, J.-F., Pearlstein, E., Simeoni-Alias, J., Clarac, F., and Vinay, L. (2003). Reversible disorganization of the locomotor pattern after neonatal spinal cord transection in the rat. J. Neurosci. 23, 1924-1932.

Payne, J. A., Rivera, C., Voipio, J., and Kaila, K. (2003). Cation-chloride cotransporters in neuronal communication, development and trauma. Trends Neurosci. 26, 199-206. doi: 10.1016/s0166-2236(03)00068-7

Pearlstein, E., Ben-Mabrouk, F., Pflieger, J.-F., and Vinay, L. (2005). Serotonin refines the locomotor-related alternations in the in vitro neonatal rat spinal cord. Eur. J. Neurosci. 21, 1338-1346. doi: 10.1111/j.1460-9568.2005. 03971.x

Pearlstein, E., Bras, H., Deneris, E. S., and Vinay, L. (2011). Contribution of 5-HT to locomotion - the paradox of Pet-1(-/-) mice. Eur. J. Neurosci. 33, 1812-1822. doi: 10.1111/j.1460-9568.2011.07679.x

Pflieger, J. F., Clarac, F., and Vinay, L. (2002). Postural modifications and neuronal excitability changes induced by a short-term serotonin depletion during neonatal development in the rat. J. Neurosci. 22, 5108-5117.

Prescott, S. A., Sejnowski, T. J., and De Koninck, Y. (2006). Reduction of anion reversal potential subverts the inhibitory control of firing rate in spinal lamina I neurons: towards a biophysical basis for neuropathic pain. Mol. Pain 2:32. doi: 10.1186/1744-8069-2-32

Rajaofetra, N., Sandillon, F., Geffard, M., and Privat, A. (1989). Pre- and post-natal ontogeny of serotonergic projections to the rat spinal cord. J. Neurosci. Res. 22, 305-321. doi: 10.1002/jnr.490220311

Ribotta, M. G. Y., Orsal, D., Feraboli-Lohnherr, D., and Privat, A. (1998a). Recovery of locomotion following transplantation of monoaminergic neurons in the spinal cord of paraplegic rats. Ann. N Y Acad. Sci. 860, 393-411. doi: 10.1111/j. 1749-6632.1998.tb09064.x

Ribotta, M. G. Y., Orsal, D., Feraboli-Lohnherr, D., Privat, A., Provencher, J., and Rossignol, S. (1998b). Kinematic analysis of recovered locomotor movements of the hindlimbs in paraplegic rats transplanted with monoaminergic embryonic neurons. Ann. N Y Acad. Sci. 860, 521-523. doi: 10.1111/j.1749-6632.1998. tb09093.x

Ribotta, M. G., Provencher, J., Feraboli-Lohnherr, D., Rossignol, S., Privat, A., and Orsal, D. (2000). Activation of locomotion in adult chronic spinal rats is achieved by transplantation of embryonic raphe cells reinnervating a precise lumbar level. J. Neurosci. 20, 5144-5152.

Sadlaoud, K., Tazerart, S., Brocard, C., Jean-Xavier, C., Portalier, P., Brocard, F., et al. (2010). Differential plasticity of the GABAergic and glycinergic synaptic transmission to rat lumbar motoneurons after spinal cord injury. J. Neurosci. 30, 3358-3369. doi: 10.1523/JNEUROSCI.6310-09.2010

Schmidt, B. J., and Jordan, L. M. (2000). The role of serotonin in reflex modulation and locomotor rhythm production in the mammalian spinal cord. Brain Res. Bull. 53, 689-710. doi: 10.1016/s0361-9230(00)00402-0

Shen, R. Y., and Andrade, R. (1998). 5-Hydroxytryptamine2 receptor facilitates GABAergic neurotransmission in rat hippocampus. J. Pharmacol. Exp. Ther. $285,805-812$.

Sławińska, U., Majczyński, H., Dai, Y., and Jordan, L. M. (2012). The upright posture improves plantar stepping and alters responses to serotonergic drugs in spinal rats. J. Physiol. 590, 1721-1736. doi: 10.1113/jphysiol.2011. 224931

Sławińska, U., Majczyński, H., and Djavadian, R. (2000). Recovery of hindlimb motor functions after spinal cord transection is enhanced by grafts of the embryonic raphe nuclei. Exp. Brain Res. 132, 27-38. doi: 10.1007/s0022199 00323

Sławińska, U., Miazga, K., Cabaj, A. M., Leszczynska, A. N., Majczyński, H., Nagy, J. I., et al. (2013). Grafting of fetal brainstem 5-HT neurons into the sublesional spinal cord of paraplegic rats restores coordinated hindlimb locomotion. Exp. Neurol. 247, 572-581. doi: 10.1016/j.expneurol.2013.02.008

Stil, A., Jean-Xavier, C., Liabeuf, S., Brocard, C., Delpire, E., Vinay, L., et al. (2011). Contribution of the potassium-chloride co-transporter KCC2 to the modulation of lumbar spinal networks in mice. Eur. J. Neurosci. 33, 1212-1222. doi: 10. 1111/j.1460-9568.2010.07592.x

Stil, A., Liabeuf, S., Jean-Xavier, C., Brocard, C., Viemari, J. C., and Vinay, L. (2009). Developmental up-regulation of the potassium-chloride cotransporter type 2 in the rat lumbar spinal cord. Neuroscience 164, 809-821. doi: 10.1016/j. neuroscience.2009.08.035

Takahashi, T. (1984). Inhibitory miniature synaptic potentials in rat motoneurons. Proc. R. Soc. Lond. B Biol. Sci. 221, 103-109. doi: 10.1098/rspb.1984. 0025 
Tokarski, K., Kusek, M., and Hess, G. (2011). 5-HT7 receptors modulate GABAergic transmission in rat hippocampal CA1 area. J. Physiol. Pharmacol. 62, 535-540.

Ung, R. V., Landry, E. S., Rouleau, P., Lapointe, N. P., Rouillard, C., and Guertin, P. A. (2008). Role of spinal 5-HT2 receptor subtypes in quipazine-induced hindlimb movements after a low-thoracic spinal cord transection. Eur. J. Neurosci. 28, 2231-2242. doi: 10.1111/j.1460-9568.2008.06508.x

van den Brand, R., Heutschi, J., Barraud, Q., Digiovanna, J., Bartholdi, K., Huerlimann, M., et al. (2012). Restoring voluntary control of locomotion after paralyzing spinal cord injury. Science 336, 1182-1185. doi: 10.1126/science. 1217416

van den Pol, A. N., Obrietan, K., and Chen, G. (1996). Excitatory actions of GABA after neuronal trauma. J. Neurosci. 16, 4283-4292.

Veasey, S. C., Fornal, C. A., Metzler, C. W., and Jacobs, B. L. (1995). Response of serotonergic caudal raphe neurons in relation to specific motor activities in freely moving cats. J. Neurosci. 15, 5346-5359.

Vinay, L., Brocard, F., Clarac, F., Norreel, J. C., Pearlstein, E., and Pflieger, J. F. (2002). Development of posture and locomotion: an interplay of endogenously generated activities and neurotrophic actions by descending pathways. Brain Res. Brain Res. Rev. 40, 118-129. doi: 10.1016/s0165-0173(02)00195-9

Vinay, L., Brocard, F., Pflieger, J., Simeoni-Alias, J., and Clarac, F. (2000). Perinatal development of lumbar motoneurons and their inputs in the rat. Brain Res. Bull. 53, 635-647. doi: 10.1016/s0361-9230(00)00397-x

Vinay, L., and Jean-Xavier, C. (2008). Plasticity of spinal cord locomotor networks and contribution of cation-chloride cotransporters. Brain Res. Rev. 57, 103-110. doi: 10.1016/j.brainresrev.2007.09.003

Wang, C., and Zucker, R. S. (1998). Regulation of synaptic vesicle recycling by calcium and serotonin. Neuron 21, 155-167. doi: 10.1016/s0896-6273(00)80523-1

Wedderburn, J. F., and Sillar, K. T. (1994). Modulation of rhythmic swimming activity in post-embryonic Xenopus laevis tadpoles by 5-hydroxytryptamine acting at 5HT1a receptors. Proc. R. Soc. Lond. B Biol. Sci. 257, 59-66. doi: 10. 1098/rspb.1994.0094
Wu, W.-L., Ziskind-Conhaim, L., and Sweet, M. A. (1992). Early development of glycine- and GABA-mediated synapses in rat spinal cord. J. Neurosci. 12, 39353945.

Xie, D. J., Uta, D., Feng, P. Y., Wakita, M., Shin, M. C., Furue, H., et al. (2012). Identification of 5-HT receptor subtypes enhancing inhibitory transmission in the rat spinal dorsal horn in vitro. Mol. Pain 8:58. doi: 10 . 1186/1744-8069-8-58

Xu, T. L., Nabekura, J., and Akaike, N. (1996). Protein kinase C-mediated enhancement of glycine response in rat sacral dorsal commissural neurones by serotonin. J. Physiol. 496, 491-501.

Xu, T. L., Pang, Z. P., Li, J. S., and Akaike, N. (1998). 5-HT potentiation of the $\mathrm{GABA}(\mathrm{A})$ response in the rat sacral dorsal commissural neurones. Br. J. Pharmacol. 124, 779-787. doi: 10.1038/sj.bjp.0701896

Zhang, W., and Grillner, S. (2000). The spinal 5-HT system contributes to the generation of fictive locomotion in lamprey. Brain Res. 879, 188-192. doi: 10. 1016/s0006-8993(00)02747-5

Conflict of Interest Statement: The authors declare that the research was conducted in the absence of any commercial or financial relationships that could be construed as a potential conflict of interest.

Received: 25 April 2014; accepted: 05 August 2014; published online: 28 August 2014. Citation: Gackière F and Vinay L (2014) Serotonergic modulation of post-synaptic inhibition and locomotor alternating pattern in the spinal cord. Front. Neural Circuits 8:102. doi: 10.3389/fncir.2014.00102

This article was submitted to the journal Frontiers in Neural Circuits.

Copyright (C) 2014 Gackière and Vinay. This is an open-access article distributed under the terms of the Creative Commons Attribution License (CC BY). The use, distribution or reproduction in other forums is permitted, provided the original author (s) or licensor are credited and that the original publication in this journal is cited, in accordance with accepted academic practice. No use, distribution or reproduction is permitted which does not comply with these terms. 